\title{
El elemento "agua" en los poemas de la Antología Poética de Joaquín Benito de Lucas
}

\author{
por Carmen González Escudero
}

Dice José Hierro en el prólogo que dedica a la "Antología Poética" de Joaquín Benito de Lucas, que el autor hace de la poesía la historia de sus años, utilizándola para salvar del olvido pedazos de su vida pues poetizar es para él revivir.

Nada más humano para el hombre, que tratar de acercar al presente, momentos que quedaron atrás y que quizás entonces no fueron importantes, que solo llegan a serlo después de un largo olvido en el tiempo y en el espacio, pero que de repente, en un instante determinado, comienzan a ser vitales al "yo" de cada uno, intentando recuperar algo que quizás nunca se quiso perder.

Sin embargo, la visión de las cosas, habrá cambiado, hay que recordarlas, a veces incluso emplear a fondo la memoria que trae y lleva los recuerdos en vaivén apresurado o suave, según haya sido su importancia; ese retorno a la memoria, embellece los recuerdos, y permite un especial deleite en la inmersión del pasado entremezclando realidad y ensueño, en aquello a lo que ya no se puede volver. Por eso quizás, el poeta dice en "Nido de Tormentas" (p. 77 Ant.).

"Recordar es lo mismo que abrasarse al tocar una estrella fugitiva

La hermosa tierra toledana que vio nacer a Joaquín Benito de Lucas, influyó sin duda alguna en la sensibilidad más íntima del poeta y en su quehacer versificador. En esa tierra en que se ensancha el Tajo formando una fértil vega, el paisaje se suaviza con respecto a otras zonas manchegas, el verdor y el frescor del regadío, los pinares y sobre todo el río, marcan una huella indeleble en el hombre y le guían en muchos momentos de su poesía.

Hay algo claro y primordial en los poemas de Joaquín Benito de Lucas, y eso es el AGUA, agua con mayúsculas, por la importancia vital para el poeta manchego, importancia quizás con dos vertientes, una atmosférica y geográfica, por su tierra de origen, siempre ávida de agua y otra, sentimental, sensitiva: su rincón natal es de los más "acuosos" de la Mancha, escuchó al río desde la infancia y el agua mece, trae, lleva en todas sus versiones, recuerdos, penas o alegrias.

$Y$ de todas las versiones del agua, tres fundamentales han atraido al poeta, .el río, presidiendo su vida y sus recuerdos, la lluvia y el mar, mar reposo, mar final, mar belleza, ese mar que le enseñara por primera vez su hermano y que tanta impresión le 
causó, mar refugio ensoñador de poetas, "mar amado, mar apetecido" que canta Manuel Machado en su poema "Ocaso".

Pera el agua-río sobresale entre todas las aguas desde siempre. En los poemas del tema "Añoranza", segundo de los ordenados por José Hierro en la Antología y perteneciente al libro "Materia de Olvido" (Madrid Ed. Rialp 1968. Premio Adonais 1967), el río, es el núcleo clave de algunos de cllos. En "La Carta Testigo" (p. 37 Ant.).

"La casa de mi infancia se levanta

sobre el rumor del río

a unos pasos de su corriente"

Nos muestra como el río, nace con él, o más bien él, con el río al que siente penetrante en sus momentos infantiles, mezclado a juegos, a seres queridos, omnipresente siempre, el río sabe decir su nombre y sus ojos de niño pequeño, se hacían más grandes para mirarle:

"Tenía cinco años

y muy grandes los ojos

con los que miraba al rio"

(versos 15, 16, 17 de "La casa testigo p. 38 Ant.).

y es el río finalmente, en este mismo poema (verso 40 ) quien le devuelve el recuerdo de momentos felices:

"y del fondo del río que es el recuerdo

hoy surgen en desorden imágenes felices"

El río es ternura, es caricia, no sólo para el alma del poeta, sino para el paisaje:

"Pinos acariciados

por la brisa del río"

(versos 1 y 2 de "La Cárcel de los Pinos, p. 35 Ant.)

y en este mismo poema, aparece el río como nostalgia, como decepción de años pasados y finalmente como un adiós, adiós a una etapa de vida, que más tarde había de recordar:

"Festoneado de un dolor de niño

que impaciente se crece

como una lluvia en el río

a la desesperanza"

(versos 16, 17, 18, 19 "La Cárcel de los Pinos" p. 36 Ant.). 
y:

"Dije al río

adiós, al puente adiós"

(Versos 42 y 43 del mismo poema).

El río también para el amor doloroso y el miedo a un padre:

"nunca hubiera creido

que fuera herencia tuya y no mi vida

igual que un golpear de barcos en la dura

costa del río, retumbando como

un antiguo dolor siento tu mano

cerrada sobre mí".

(versos 1 al 6 de "La Herencia" p. 39 Ant.).

Pero el río es más que nada nostalgia insistente en el poeta, que en sus años berlineses echa de menos, recordando su terruño, así en "Frio del Norte" (poema de $\mathrm{KZ}$ Campo de concentración, Las Palmas, colec. San Borondón, Imp. Lezcano 1970) dice en los versos 18 al 20 p. 44 Ant.).

"Sobre el río

de mi ciudad, cuando salga

el sol volarán vencejos

bajo sus puentes de plata"

y más tarde a su regreso, ya en Madrid, le hace recordar la nostalgia que de él sentía desde Berlín en su poema "El regreso", de "Memorial del Viento" (Orihuela Ed. Ayuntamiento Imp. Serón premio Miguel Hernández 1976), nos hace sentir la soledad alemana los años en que estuvo ausente el rumor querido que siempre le acunara en las etapas de la infancia, en metáfora de puentes y de río:

"Y volvían temblando

con el rumor del río

de mi ciudad que no veía y sonaba"

(versos $10,11,12$ ).

"Su río

que atravesó los puentes de mi infancia"

(versos 19 y 20 ).

Sigue siendo nostalgia en "Golondrinas del Puente" ("Plancton" Salamanca Colc. Alamo 1976), cuando lo entremezcla a los sueffos y a las golondrinas, al calor del hogar y a la ausencia. 
"Igual que sueños al nacer el día"

(Golondrinas del Puente verso 1 p. 47 Ant.).

"Surgen las golondrinas sobre el río"

(verso 9).

"Y siendo el calor que da la casa

de mi niñez junto al rumor del río"

(versos 12, 13).

"¿quién ha quitado el río de mi boca?

(verso 21)

El río le sirve a veces para acompañarlo a recuerdos, a retazos de su vida olvidados, como hace en "Luces Apagadas" (Plancton 1976) en los versos 4, 5, 6, 7 p. 48, 49 Ant.).
"A través de los años como un río
a su orilla me veo
acechando momentos que creía
ya perdidos..."

Y otros, el río es la duda respecto a la vida, como en "Otras Lluvias" p. 50 Ant. vrsos 5 y 6.

"Puede ser que vivir no sea tan solo ese avanzar de río"

Para el amigo muerto, ciclista al que encontraba en sus entrenamientos matutinos, el río, el alba, es el lugar de encuentro, de cita inesperada que nunca tuvo el presentimiento del amargo final, de la muerte sin el fiel compañero que corria bajo el puente, de aquellas alboradas de pedales, sin el eco del agua que después fue lágrimas; por eso dice en "La Rueda del Tiempo" ("Memorial del Viento" Orihuela 1978).

\footnotetext{
"Alguna vez cuando la luz se alzaba sobre el canto del río de esa ciudad que en tí se hace memoria nos cruzamos".
}

(versos 19 a 22 p. 53 Ant.).

"Si en aquellos momentos te hubiera acompañado 
el río que hoy te llora

desesperadamente"

(versos $46-48$ p. 54 Ant.).

Y el río es también amor, es un nombre navegando por el agua

"El río

de tu nombre sonaba"

("Sin nombre" de "Materia de Olvido" versos 24-25 p. 61 Ant.).

Con el poema "Celestina a los amantes" (Antínomia 1983), pone en boca de esta, sentencias amorosas en las que el río es metáfora de la voz enamorada:

"No busquéis la palabra verdadera

ni oro en el río, ni en el mar distancias"

(versos 1 y 2 p. 7 Ant.).

"río

de música que corre entre sus brazos"

(versos 21 y 22 p. 71 Ant.).

Metáfora es también en el poema "Celestina ante el cuerpo de Calix to" (Antinomia), en el verso 15, comparando al muchacho enamorado que fuera Calixto en vida con el rumor del río:

"Perfume de jardín, rumor de río"

Con el río se pregunta en "Humo de un beso" ("Campo de Espuma, Madrid 1983) si volverá a encontrar lo bello ya esfumado, un amor en el recuerdo, en la distancia, un imposible retorno.

¿Te volveré a encontrar pájaro o barco

reptil o nube, aguamarina o río?

(versos 10 y 11 p. 78 Ant.).

Vuelve a ser el río hermosa metáfora, destructor esta vez, símbolo de miedo, de angustia, de tristeza, de ansiada libertad de los perseguidos, en el poema "La Caravana" ("Las Tentaciones" Madrid 1964) cuando en los versos 13 a 17 dice:

"Ni el beso,

ni el canto, ni la danza

les redimen del río

que por su pecho avanza

destructor y sonoro" 
Por último, hace de Almería, de sus hombres, de su historia, un río secreto y misterioso:

"De lo hondo renacen, tal un río secreto y misterioso"

("Piedra Dormida" V. 11 y 12 p. 87 Ant.).

Y si el río es un correr de vida, de recuerdos, de lágrimas, el mar, descanso de los ríos, donde dejan sus largas fatigas de discurrir por vegas y por piedras, el mar es para el poeta, a veces redención o alegría como en los versos 3 al 6 y 16, 17 de "Con las Sombras" (Las Tentaciones 1964).

"Entre sombras se eleva

la ruidosa manana

y el mar sobre un abismo

de sombras se levanta"

"Pero que se levantan

sobre el mar y la tierra"

o en los versos 14 y 22 de "Estás Herido" ("Las Tentaciones" p. 18 Ant.).

"Eres como un pedazo azul de mar"

"A la sombra del mar, mientras el ruido"

El mar es alegría en "Cortejo de Sombras" (Plancton).

¿Es verdad o es mentira esos instantes

en que sentimos que la vida toda

se nos llena de luz igual que un parque

o como el mar, de espuma y de gaviotas?

Es ensueño y suefio en el verso 1 de "Azul y Grande" y en 1 de "Sueño Apasionado" (Plancton 1976).

"El mar a veces es como la noche"

(p. 22 Ant.)

"En medio de la noche o del mar sumergidos"

(p. 22 Ant.).

En "Doradamente Azul" (Memorial del Viento 1978), el mar es descanso, es final y es esperanza para el hombre

"El último trayecto

que termina en el mar" 
(Versos 18 y 19$)$.

"Dorados hacia el mar de la epseranza"

(verso 32 p. 29 Ant.).

$\mathrm{Y}$ es indestructible como el tiempo y no renuncia a nada, en los versos 17 y $18 \mathrm{de}$ "El Regreso" (Memorial del Viento 1978)

"El tiempo no renuncia

a su conquista como el mar"

Se convierte en olvido, posibilidad de olvido en el verso 2 de "Lo irremediable" (Materia de Olvido 1968).

"El tiempo hace justicia

y ensancha el mar"

Y sirve a Celestina de metáfora, para definir la poca consistencia de las palabras, aunque éstas sean de amor y suenen hermosas, dice Celestina a los amantes:

"Las palabras son flechas

que por el aire se pierden, barcos que en el mar naufragan"

(versos 5, 6 y 7 de "Celestina a los Amantes" "Antinomia") y es el recuerdo de amor de Melibea, recuerdo en calma, pero que no muere, en los versos 11, 12 y 13 de "Melibea a Calixto".

"Juntos hicimos esa travesía

en barcos de cristal hacia las islas

de un mar hoy sin color ni movimiento"

El mar es sendero hacia el amor en "Vereda de Espuma" (Campo de Espuma 1983).

¿ves el camino que la brisa ha abierto

como una estela sobre el mar?

(versos 1 y 2)

Y es cuerpo de la amada ¡bella metáfora! en "Música acuática":

"Qué hermoso es recorrer tu cuerpo, playa

y caldero, dársena y abierto

mar y mis caricias"

(versos $1,2,3$ ). 
"Poco a poco

te sumerges, o sube el mar"

(versos 12,13).

"tu cuerpo, nido vivo

de peces y de helechos, de corales

y de estrellas, conserva

si estás en el fondo del amor, un ruido

más hondo que el del mar"

(versos 19 al 23).

Hay un momento primordial del mar para el poeta cuando por primera vez lo vio y así lo canta en "la Cárcel de los Pinos" (Añoranza p. 35 Ant.) en los tres primeros versos:

"Y el mar me abrió sus puertas

Tardes que nunca olvido

frente a la espuma".

Es un mar concreto, físico, el Mediterráneo, en "Tierras de Líbano" (Memorial del Viento 1978) y así lo nombra en los versos 9 al 13 del poema.
"Y viajé
desde sus altas copas
del Mar Mediterráneo
a besar la naciente
y fría espuma de Trípoli"

A veces ese elemento AGUA en sus tres versiones, lluvia, río, mar, aparece entremezclado en algún poema. Ocurre así en "Celestina a los Amantes" (Antinomia 1983) donde el mar, son las palabras, pues en él se diluyen, el río es la voz, y la lluvia la pasión que corre por la sangre de Calixto.

"Barcos que en el mar naufragan"

(verso 7)

"Río de música que corre entre tus brazos

(versos 21 y 22)

"Y que descarga por su sangre

como una lluvia"

(versos 12 y 13) 
Otros, es la lluvia quien comparte con el río un sentimiento, asi en "Noche de Silencio", después de los versos dedicados al río (del 18 al 21 p. 44 de Ant.) dice:

"Puentes que hasta mi memoria como lluvia se alargan"

(versos 22, 23)

Se alargan y le atraen en el recuerdo, y en "Otras Lluvias" (p. 50 Ant.) ante la duda de los versos 5 y 6 :

"Puede ser que vivir no sea tan solo ese avanzar del río"

la posibilidad de que "vivir" sea lluvia,

"sino retroceder hacia otras lluvias"

(verso 10 p. 44 Ant.).

La lluvia siempre aparece en los poemas como amiga ya sea transportando recuerdos (versos 1 y 2 de "Tierras de mi Infancia" p. 49 Ant.).

"La lluvia que cae no es lluvia son recuerdos"

o son horas recordadas ("La Trampa" verso 12 p. 26)

"Pero igual que la lluvia recordaba"

o es amiga y aliada, en mayo y sabe pronunciar nombres y se puede hablar con ella, es una lluvia buena:

"Aunque creo

que la lluvia es amiga

y aliada"

(versos 1 a 3 p. 34 Ant.)

"Pero era así, era una lluvia buena"

(verso 27 p. 34 Ant.).

E incluso en el odio alemán, la lluvia canta:

"Mientras la lluvia canta

mientras el odio enturbia 
los cielos de Alemania"

(versos 24, 25, 26 de "Frío del Norte" p. 43 Ant.).

Recuerdo fue la lluvia para D. Quijote, en ese poema de poeta manchego a caballero manchego:

"Escenas de su infancia

adivinadas

a través de la lluvia"

(verso 11 de "último encuentro de Don Quijote con Dulcinea").

Y era su ilusión, lluvia fueron las campanas, en ese mismo poema

"Finas

campanas como lluvia"

(verso 7, p. 65 Ant.).

$Y$ la lluvia es sueño de amor para enamorados, Calixto y Melibea:

"han sido solo un sueño en nuestros brazos

como la lluvia"

(versos 3 y 4 "Melibea a Calixto" p. 72 Ant.).

Lluvia como lluvia, cae en el jardín de los enamorados:

"Donde la lluvia cae como la lluvia"

(verso 9 "Humo de unbeso" p. 78 Ant.).

Mar y lluvia, lluvia y río, para amar, soñar, sentir paz y olvido, para guardar secretos, para revivir el tiempo, para al correr la vida llenarla de recuerdos. Estos tres elementos acuosos, tal como los emplea Benito de Lucas, nos transportan a un remanso de paz, a un bienestar intimo enormemente apetecible en estos tiempos de agresividad y prisa; AGUA como símbolo de lo puro, lo bello, de lo que vale la pena salvar en cada vida.

Las distintas emociones que transmiten estos poemas invitan a la tentación de analizar el propio sentimiento, a hacer un recorrido por antiguos recuerdos olvidados, acaso un río o un mar o un sueño que todos hemos tenido alguna vez y a no perder la ilusión ni la esperanza, porque la esperanza dice el poeta "nunca abandona el pecho del hombre". 